\title{
Regulation of mRNA translation controls seed germination and is critical for seedling vigor
}

\author{
Marc Galland $^{1,2 \dagger}$ and Loïc Rajjou ${ }^{1,2 *}$ \\ ${ }^{1}$ INRA, Institut Jean-Pierre Bourgin, UMR 1318 INRA/AgroParisTech, ERL Centre National de la Recherche Scientifique \\ 3559, Laboratory of Excellence "Saclay Plant Sciences" (LabEx SPS), Versailles, France, ${ }^{2}$ Chair of Plant Physiology, \\ AgroParisTech, Paris, France
}

Keywords: seed, plant, dormancy, germination, longevity, translation, mRNA, proteins

OPEN ACCESS

Edited by:

Ganesh Kumar Agrawal,

Research Laboratory for Biotechnology and Biochemistry,

Nepal

Reviewed by:

Ján A. Miernyk,

University of Missouri, USA

Pingfang Yang,

Chinese Academy of Sciences, China

${ }^{*}$ Correspondence:

Loïc Rajjou,

loic.rajjou@agroparistech.fr

${ }^{\dagger}$ Present Address: Marc Galland,

Department of Plant Physiology,

Swammerdam Institute for Life Sciences, University of Amsterdam, Amsterdam, Netherlands

Specialty section:

This article was submitted to Plant Proteomics,

a section of the journal Frontiers in Plant Science

Received: 28 February 2015 Accepted: 09 April 2015 Published: 28 April 2015

Citation:

Galland M and Rajjou L (2015) Regulation of $m R N A$ translation controls seed germination and is

critical for seedling vigor

Front. Plant Sci. 6:284.

doi: 10.3389/fp/s.2015.00284
The control of seed germination capacity is a multi-level molecular process including, epigenetic, transcriptional, post-transcriptional, translational, and post-translational regulation (Rajjou et al., 2012). Since the beginning of the twenty-first century, a wide range of genetic, genomic, and post-genomic approaches have been used to decipher the underlying molecular and biochemical bases of dormancy, vigor, and longevity. In particular, the regulation of stored mRNA translation appears as an essential determinant of seed quality. Indeed, proteomic approaches unveiled the main importance of protein synthesis during seed germination (Rajjou et al., 2004; Kimura and Nambara, 2010), as well as factors involved in seed longevity (Rajjou et al., 2008). In aged seeds, the protein synthesis capacity decline together with the loss of germination potential. In contrast, both dormant and non-dormant Arabidopsis seeds display equal translational activity 1 day after imbibition although distinct protein pools are synthetized (Chibani et al., 2006). In sunflower, seed dormancy release by after-ripening would not be related to transcriptomic changes but associated with oxidation of specific subsets of stored mRNAs, thus impairing their translation (Bazin et al., 2011; Meimoun et al., 2014). In the aim to get a comprehensive view of translational control of seed dormancy and germination in sunflower, a microarray-based translatome analysis was performed, highlighting differential accumulation of polysome-associated mRNAs between dormant and non-dormant imbibed seeds (Layat et al., 2014). However, multiple ribosomes are not necessarily translationally active. Indeed, it has been observed that both active and stalled ribosomes are able to co-sediment during isolation of polysome complexes (Sivan et al., 2007). As a result, polysome profiling does not fully discriminate translationally active from repressed mRNAs. This concern should be particularly true in the case of dry seeds where polysomes would not be functional. Indeed, it has been observed that the ribosomes are condensed into regions consisting of closely packed particles in the dry seed related with a latent potential for protein synthesis (Chapman and Rieber, 1967). A rapid polysome formation occurs during early germination related with the transition from a dry and quiescent state to a fully imbibed and metabolically active state. In non-dormant Arabidopsis seeds, the comparison between the transcript changes and the protein changes from dry to 1d-imbibed seeds showed strong discordance (Galland et al., 2012). This is in accordance with previous work in plants reporting that the abundance of a transcript does not necessarily reflect its translation (BaileySerres et al., 2009). It is likely that when conditions are favorable for the maintenance of seed dormancy, translational selectivity will promote the translation of stored mRNA associated with maturation program (Arc et al., 2012). The time course of seed germination is related to both sequential and selective mRNA translation emphasizing a fine regulation of the translational machinery (Galland et al., 2014). Indeed, the temporal profiling of protein synthesis highlights that Arabidopsis seed germination consists of a series of sequential events overlapping with the three canonical phases of this process namely, water uptake (Phase I), lag phase (Phase II), and 
radicle growth (Phase III). Germination sensu stricto (i.e., prior to radicle emergence) refers to phases I and II while phase III consists of seedling growth resumption accompanied by both cell elongation and cell division. In the early step of water uptake, germination begins with a resumption of maturation program through the translation of mRNA associated with storage proteins and tolerance desiccation. This relates to an important checkpoint where, in a favorable environment, germination of non-dormant seeds is accompanied by a radical change in their translational program. Indeed, in the lag phase a sequential translation of mRNA related with antioxidant mechanisms, cell detoxification, protein fate, energy, and amino acids metabolism occurs. At the end of this lag phase, proteins involved in protein degradation and nitrogen remobilization are neosynthetized in preparation for the seedling growth. Therefore, it can be assumed that mRNA translation and protein post-translational modifications constitute the main levels of control for germination completion (Arc et al., 2011; Rajjou et al., 2012). These processes are highly regulated in plants and represent rapid and efficient way to cope with environmental variations. The regulation of mRNA translation is extremely complex and not explored enough in seed biology. Still the seed would be an excellent model for studying translation and selectivity mechanisms due to the presence of different mRNA populations in the dry mature seed. It seems relevant to conduct a comprehensive investigation about the mRNA recruitment by the nuclear cap-binding complex (CBC) and by the cytoplasmic mRNA CBC (eIF4F) since several phenotypes were observed in mutant seeds affected in genes involved in these mechanisms. The eIF4F and polyA-binding protein (PABP) promotes the transcript stabilization and the ribosome-mRNA interactions (Gingras et al., 1999; Hinnebusch and Lorsch, 2012). The exon junction complex (EJC) would be involved in plant translational selectivity since it links the different aspects of mRNA biogenesis, such as transcription, splicing, export,

\section{References}

Arc, E., Chibani, K., Grappin, P., Jullien, M., Godin, B., Cueff, G., et al. (2012). Cold stratification and exogenous nitrates entail similar functional proteome adjustments during Arabidopsis seed dormancy release. J. Proteome Res. 11, 5418-5432. doi: 10.1021/pr3006815

Arc, E., Galland, M., Cueff, G., Godin, B., Lounifi, I., Job, D., et al. (2011). Reboot the system thanks to protein post-translational modifications and proteome diversity: how quiescent seeds restart their metabolism to prepare seedling establishment. Proteomics 11, 1606-1618. doi: 10.1002/pmic.201000641

Bailey-Serres, J., Sorenson, R., and Juntawong, P. (2009). Getting the message across: cytoplasmic ribonucleoprotein complexes. Trends Plant Sci. 14, 443-453. doi: 10.1016/j.tplants.2009.05.004

Bazin, J., Langlade, N., Vincourt, P., Arribat, S., Balzergue, S., El-MaaroufBouteau, H., et al. (2011). Targeted mRNA oxidation regulates sunflower seed dormancy alleviation during dry after-ripening. Plant Cell 23, 2196-2208. doi: $10.1105 /$ tpc.111.086694

Catusse, J., Strub, J. M., Job, C., Van Dorsselaer, A., and Job, D. (2008). Proteomewide characterization of sugarbeet seed vigor and its tissue specific expression. Proc. Natl. Acad. Sci. U.S.A. 105, 10262-10267. doi: 10.1073/pnas.0800585105

Chapman, J. A., and Rieber, M. (1967). Distribution of ribosomes in dormant and imbibed seeds of Pisum arvense: electron-microscopic observations. Biochem. J. 105, 1201 surveillance, and nonsense-mediated mRNA decay (NMD) (Nyikó et al., 2013). Particular attention should be paid to DEAD-box RNA helicases presumably involved in translation by assisting ribosome maturation (Cordin et al., 2006). Indeed, the Plant RNA helicase75 (PRH75) have been shown to be a target of the Protein Isoaspartyl Methyltransferase 1 (PIMT1) that repair non-functional isoAsp residues upon seed deterioration (Nayak et al., 2013). This is probably an explanatory element of the impairment of seed vigor and longevity in PIMT-deficient genotypes (Ogé et al., 2008; Verma et al., 2013). In addition, the cap-independent process through direct mRNA recruitment by ribosomal subunits on an internal ribosome entry sites (IRES) would be possible since mature seeds have proteins named ITAFs (IRES-specific cellular trans-acting factors) involved in this process (Catusse et al., 2008). To date, mRNA decay and translational repression by small RNAs remain non-addressed in seed biology but may be a determinant way for translational selectivity. The impact on translation of the plant TOR (target of rapamycin) protein kinases pathway is associated with abscisic acid (ABA) and growth processes in plants (Deprost et al., 2007). Further investigation of TOR-dependent phosphorylation signaling in seed dormancy, germination, and longevity appears required. The involvement of different ribosomal subunits and their post-translational regulation also remains unexplored in the control of seed germination. Thus, through this reasoning about the central role of translational regulation in the control of germination, future work on this issue should provide a better understanding of the mechanisms underlying seed physiology and provide robust markers for seed vigor.

\section{Acknowledgments}

Our heartfelt gratitude to the French Ministry of Industry (FUI, NUTRICE) and the European Commission's Seventh Framework Programme (KBBE, EcoSeed) for funding our research.
Chibani, K., Ali-Rachedi, S., Job, C., Job, D., Jullien, M., and Grappin, P. (2006). Proteomic analysis of seed dormancy in Arabidopsis. Plant Physiol. 142, 1493-1510. doi: 10.1104/pp.106.087452

Cordin, O., Banroques, J., Tanner, N. K., and Linder, P. (2006). The DEAD-box protein family of RNA helicases. Gene 367, 17-37. doi: 10.1016/j.gene.2005.10.019

Deprost, D., Yao, L., Sormani, R., Moreau, M., Leterreux, G., Nicolai, M., et al. (2007). The Arabidopsis TOR kinase links plant growth, yield, stress resistance and mRNA translation. EMBO Rep. 8, 864-870. doi: 10.1038/sj.embor.7401043

Galland, M., Huguet, R., Arc, E., Cueff, G., Job, D., and Rajjou, L. (2014). Dynamic proteomics emphasizes the importance of selective mRNA translation and protein turnover during Arabidopsis seed germination. Mol. Cell. Proteomics 13, 252-268. doi: 10.1074/mcp.M113.032227

Galland, M., Job, D., and Rajjou, L. (2012). The seed proteome web portal. Front. Plant Sci. 3:98. doi: 10.3389/fpls.2012.00098

Gingras, A. C., Raught, B., and Sonenberg, N. (1999). eIF4 initiation factors: effectors of mRNA recruitment to ribosomes and regulators of translation. Annu. Rev. Biochem. 68, 913-963. doi: 10.1146/annurev.biochem.68.1.913

Hinnebusch, A. G., and Lorsch, J. R. (2012). The mechanism of eukaryotic translation initiation: new insights and challenges. Cold Spring Harbor Perspect. Biol. 4:a011544. doi: 10.1101/cshperspect.a011544

Kimura, M., and Nambara, E. (2010). Stored and neosynthesized mRNA in Arabidopsis seeds: effects of cycloheximide and controlled deterioration 
treatment on the resumption of transcription during imbibition. Plant Mol. Biol. 73, 119-129. doi: 10.1007/s11103-010-9603-x

Layat, E., Leymarie, J., El-Maarouf-Bouteau, H., Caius, J., Langlade, N., and Bailly, C. (2014). Translatome profiling in dormant and nondormant sunflower (Helianthus annuus) seeds highlights post-transcriptional regulation of germination. New Phytol. 204, 864-872. doi: 10.1111/nph.13002

Meimoun, P., Mordret, E., Langlade, N. B., Balzergue, S., Arribat, S., Bailly, C., et al. (2014). Is gene transcription involved in seed dry after-ripening? PLoS ONE 9:e86442. doi: 10.1371/journal.pone.0086442

Nayak, N. R., Putnam, A. A., Addepalli, B., Lowenson, J. D., Chen, T., Jankowsky, E., et al. (2013). An Arabidopsis ATP-dependent, DEAD-box RNA helicase loses activity upon IsoAsp formation but is restored by PROTEIN ISOASPARTYL METHYLTRANSFERASE. Plant Cell 25, 2573-2586. doi: 10.1105/tpc.113.113456

Nyikó, T., Kerényi, F., Szabadkai, L., Benkovics, A. H., Major, P., Sonkoly, B., et al. (2013). Plant nonsense-mediated mRNA decay is controlled by different autoregulatory circuits and can be induced by an EJC-like complex. Nucleic Acids Res. 41, 6715-6728. doi: 10.1093/nar/gkt366

Ogé, L., Bourdais, G., Bove, J., Collet, B., Godin, B., Granier, F., et al. (2008). Protein repair L-isoaspartyl methyltransferase 1 is involved in both seed longevity and germination vigor in Arabidopsis. Plant Cell 20, 3022-3037. doi: $10.1105 /$ tpc. 108.058479

Rajjou, L., Duval, M., Gallardo, K., Catusse, J., Bally, J., Job, C., et al. (2012). Seed germination and vigor. Аnnu. Rev. Plant Biol. 63, 507-533. doi: 10.1146/annurev-arplant-042811-105550

Rajjou, L., Gallardo, K., Debeaujon, I., Vandekerckhove, J., Job, C., and Job, D. (2004). The effect of alpha-amanitin on the Arabidopsis seed proteome highlights the distinct roles of stored and neosynthesized mRNAs during germination. Plant Physiol. 134, 1598-1613. doi: 10.1104/pp.103. 036293

Rajjou, L., Lovigny, Y., Groot, S. P., Belghazi, M., Job, C., and Job, D. (2008). Proteome-wide characterization of seed aging in Arabidopsis: a comparison between artificial and natural aging protocols. Plant Physiol. 148, 620-641. doi: $10.1104 /$ pp. 108.123141

Sivan, G., Kedersha, N., and Elroy-Stein, O. (2007). Ribosomal slowdown mediates translational arrest during cellular division. Mol. Cell. Biol. 27, 6639-6646. doi: 10.1128/MCB.00798-07

Verma, P., Kaur, H., Petla, B. P., Rao, V., Saxena, S. C., and Majee, M. (2013). PROTEIN L-ISOASPARTYL METHYLTRANSFERASE2 is differentially expressed in chickpea and enhances seed vigor and longevity by reducing abnormal isoaspartyl accumulation predominantly in seed nuclear proteins. Plant Physiol. 161, 1141-1157. doi: 10.1104/pp.112. 206243

Conflict of Interest Statement: The authors declare that the research was conducted in the absence of any commercial or financial relationships that could be construed as a potential conflict of interest.

Copyright $\odot 2015$ Galland and Rajjou. This is an open-access article distributed under the terms of the Creative Commons Attribution License (CC BY). The use, distribution or reproduction in other forums is permitted, provided the original author(s) or licensor are credited and that the original publication in this journal is cited, in accordance with accepted academic practice. No use, distribution or reproduction is permitted which does not comply with these terms. 